\title{
Epidemiological investigation of perinatal deaths in Recife-Pernambuco: a quality assessment
}

\author{
Avaliação da qualidade da investigação epidemiológica dos óbitos perinatais, Recife-Pernambuco
}

Evaluación de la calidad de la investigación epidemiológica de las muertes perinatales, Recife-Pernambuco

\author{
Isabela de Lucena Heráclio', Maysa Almeida da Silva", Mirella Bezerra Rodrigues Vilela', \\ Conceição Maria de Oliveira"I', Paulo Germano de Frias ${ }^{\mathrm{IV}}$, Cristine Vieira do Bonfim' \\ ' Universidade Federal de Pernambuco. Recife, Pernambuco, Brazil. \\ "Fundação Joaquim Nabuco, Social Research Directorate. Recife, Pernambuco, Brazil. \\ "II Centro Universitário Maurício de Nassau. Recife, Pernambuco, Brazil. \\ IV Instituto de Medicina Integral Prof. Fernando Figueira, Study Group on Health Assessment. Recife, Pernambuco, Brazil.
}

How to cite this article:

Heráclio IL, Silva MA, Vilela MBR, Oliveira CM, Frias PG, Bonfim CV. Epidemiological investigation of perinatal deaths in Recife-Pernambuco: a quality assessment. Rev Bras Enferm [Internet]. 2018;71(5):2519-26. DOI: http://dx.doi.org/10.1590/0034-7167-2017-0916

Submission: 01-09-2018

Approval: 05-23-2018

\section{ABSTRACT}

Objective: to evaluate the completeness of perinatal death investigation sheets, stratified by age components. Method: descriptive study carried out in Recife, PE, in 2014. Among 308 perinatal deaths, 46 were excluded from this study due to association with congenital malformations, and 7 due to missing investigation sheets. Analysis included 255 deaths (160 fetal deaths, and 95 preterm neonatal deaths). The degree of completeness of 98 variables was calculated. They were aggregated into six blocks: identification, prenatal care, birth care, family characteristics, occurrence of death and conclusions and recommendations. Results: the median rate of completeness for perinatal death investigation sheets was $85.7 \%$ ( $82.8 \%$ for records of fetal deaths and $89.5 \%$ for records of preterm neonatal deaths). The best-filled information block was "identification" (96.1\%), as well as its components: fetal (94.7\%) and preterm neonatal (97.9\%). The worst was "prenatal care" (69.8\%), along with its components: fetal (73.8\%) and preterm neonatal (67.4\%). Conclusion: investigation sheets had good completeness; there were differences between variables and components of perinatal death.

Descriptors: Perinatal Mortality; Epidemiological Surveillance; Vital Statistics; Health Information Systems; Public Health.

\section{RESUMO}

Objetivo: avaliar a completitude das variáveis das fichas de investigação dos óbitos perinatais, estratificadas por componentes etários. Método: estudo descritivo realizado no Recife-PE, em 2014. Dos 308 óbitos perinatais, excluíram-se 46 decorrentes de malformação congênita e 7 fichas não localizadas. A análise contou com 255 óbitos (160 fetais e 95 neonatais precoces). Calculou-se o grau de completitude de 98 variáveis agregadas em seis blocos: identificação, pré-natal, nascimento, características da família, ocorrência do óbito e conclusões e recomendações. Resultados: a mediana de preenchimento do perinatal foi 85,7\% (82,8\% fetal e 89,5\% neonatal precoce). O bloco de melhor preenchimento foi "identificação para o perinatal" (96,1\%) e seus componentes, fetal (94,7\%) e neonatal precoce $(97,9 \%)$, e o de pior foi "pré-natal" (69,8\%), acompanhado pelo fetal (73,8\%) e neonatal precoce (67,4\%). Conclusão: observouse completitude boa das fichas de investigação, existindo diferenças entre as variáveis e os componentes do óbito perinatal.

Descritores: Mortalidade Perinatal; Vigilância Epidemiológica; Estatísticas Vitais; Sistema de Informação em Saúde; Saúde Pública.

\section{RESUMEN}

Objetivo: evaluar la completitud de las variables de las fichas de investigación de las muertes perinatales, estratificadas por componentes de edad. Método: estudio descriptivo realizado en Recife-PE, en 2014. De las 308 muertes perinatales, se excluyeron 46 derivadas de malformación congénita y 7 fichas no localizadas. El análisis incluyó 255 muertes (160 fetales y 95 neonatales precoces). Se calculó el grado de completitud de 98 variables agregadas en seis bloques: identificación, prenatal, nacimiento, características de la familia, ocurrencia del óbito, y conclusiones y recomendaciones. Resultados: la mediana de Ilenado del perinatal fue $85,7 \%$ (82,8\% fetal y 89,5\% neonatal precoz). El bloque de mejor Ilenado fue "identificación 
para el perinatal" $(96,1 \%)$ y sus componentes, fetal $(94,7 \%)$ y neonatal precoz $(97,9 \%)$, y el de peor fue "prenatal" $(69,8 \%)$, acompañado por el fetal $(73,8 \%)$ y neonatal precoz $(67,4 \%)$. Conclusión: se observó una buena completitud de las fichas de investigación, existiendo diferencias entre las variables y los componentes del óbito perinatal.

Descriptores: Mortalidad Perinatal; Monitoreo Epidemiológico; Estadísticas Vitales; Sistemas de Información en Salud; Salud Pública.

\section{CORRESPONDING AUTHOR Cristine Vieira do Bonfim E-mail: cristine.bonfim@uol.com.br}

\section{INTRODUCTION}

Deaths in the perinatal period, which range from the 22nd week of gestation to the sixth day of life, are evidence of socioeconomic vulnerabilities and compromised quality of maternal and child healthcare $^{(1-2)}$. Worldwide, there are an estimated 4.9 million perinatal deaths per year, including 2 million fetal deaths and 2.9 million preterm neonatal deaths. The perinatal death estimate for Brazil is $53,170^{(3)}$; most deaths were preventable and often remain uncounted ${ }^{(4)}$.

Although the World Health Organization (WHO) launched in 2014 a plan of action to significantly reduce preventable deaths and fetal deaths by $2035^{(5)}$, the organization's Sustainable Development Goals did not prioritize the monitoring of perinatal mortality rate, keeping it out of the public's attention ${ }^{(6)}$. However, countries that have vital statistics information systems with good coverage and reliable data can acquire knowledge on their perinatal epidemiological situation, planning interventions in favor of maternal and newborn health ${ }^{(7)}$.

Given the absence and insufficiency of vital information and better insight into perinatal deaths, death surveillance by combining maternal sociodemographic data, risk factors, healthcare histories and their nonconformities facilitates the understanding of the circumstances around the occurrence of death ${ }^{(5-6)}$. In Brazil, despite the fact that infant and fetal death surveillance became mandatory in the health services that make up the Unified Health System (SUS) only in 2010, there were several successful death surveillance experiences prior to the constitution of this normative base ${ }^{(8-9)}$.

Studies evaluating all stages of the death surveillance process and its investigative tools are still meager in the country ${ }^{(10)}$. Currently available analyzes on the consistency of information obtained from household interviews and institutional records, and on the completeness of investigation sheet variables, are insufficient. The same is not observed in respect to declarations of live births and deaths, which are heavily studied ${ }^{(11)}$.

Knowledge on variables presenting non-null records in perinatal death investigation sheets may contribute to improvements in terms of gathering vital statistics, investigation quality, epidemiological situation diagnosis, evaluation of maternal and child healthcare, and planning of perinatal public policies.

\section{OBJECTIVE}

To evaluate the completeness of variables in perinatal death investigation sheets, stratified by age components.

\section{METHOD}

\section{Ethical aspects}

This research project was approved by the Research Ethics Committee of the Health Sciences Center of the Federal
University of Pernambuco on July 1, 2015 and obtained an approval from the Health Secretariat of Recife.

\section{Study design, place and period}

This was a descriptive study on the completeness of perinatal death investigation sheets carried out in 2014 with residents of Recife, PE. Recife is the capital of the state of Pernambuco, located in the Northeast region of Brazil, which in 2014 had 1,608,488 inhabitants, distributed over $218 \mathrm{~km}^{2}, 94$ neighborhoods and six sanitary districts $^{(12)}$. Surveillance of infant and fetal death was implemented in 2002, after the situation of infant mortality was analyzed. Death surveillance was collectively constructed by public managers and healthcare workers. Its goals were: to identify failures in maternal and child healthcare, defining their avoidability; to improve the quality of information systems and employ them in the research, planning and adoption of measures aimed at reducing infant mortality ${ }^{(9)}$.

\section{Inclusion and exclusion criteria}

In 2014, 308 perinatal deaths were recorded in the Mortality Information System (SIM), including those associated with mothers who resided in Recife. Perinatal deaths due to congenital malformations and those with missing investigation sheets were excluded.

\section{Data source}

Mortality Information System (SIM) and perinatal death investigation sheets. This sheet includes all the variables that the Ministry of Health requires to be monitored $^{(4)}$, alongside others that are of local interest.

\section{Study protocol, analysis of results and statistics}

Structured variables $(\mathrm{n}=98)$ were analyzed in eight blocks: notification and investigation of death; identification; prenatal care; birth care; family characteristics; occurrence of death; and conclusions, recommendations and preventive measures.

Completeness was analyzed by the proportion of filled fields in each variable and each block, and presented according to fetal and preterm neonatal components. Investigation sheet data were coded and typed with double entry, for inconsistency analysis and to minimize errors, using the Epi Info software, version 7.0. In order to classify the filling level of the variables, the scale proposed by Romero and Cunha ${ }^{(13)}$ was adopted: excellent (more than $95.0 \%$ filled); good (90.1 to $95.0 \%$ ); regular (80.1 to $90.0 \%$ ); poor (50.1 to $80.0 \%$ ) and very poor ( $50 \%$ or less). Descriptive statistics were performed through R software, version 3.2.2.

\section{RESULTS}

Among 308 perinatal deaths, $46(14.9 \%)$ were excluded from the study because they were associated with congenital 
malformation, and 7 (2.3\%) due to missing investigation sheets. Analysis included 255 deaths (160 fetal deaths, and 95 preterm neonatal deaths).

The variables analyzed presented a median filling level of $85.7 \%$. For fetal and preterm neonatal deaths, the median filling level was $82.8 \%$ and $89.5 \%$, respectively. In the perinatal general category, the best-filled block of variables was "identification," with a median filling level of $96.1 \%$. The worst was "prenatal care," with $69.8 \%$. In both perinatal components, the "identification" block presented the best completeness (fetal: 94.7\%; preterm neonatal: $97.9 \%$ ). Similarly, the block with the worst completeness among components was prenatal care (73.8\% and $67.4 \%$ ) (Table 1).

Table 2 presents data on death identification. Among a total of 11 variables, 7 had "excellent" completion. The variable with the lowest completion proportion $(40.0 \%=$ "very poor") in perinatal death investigation sheets was "partner occupation." Among 19 variables related to prenatal care, 4 were classified as having "excellent" completion and 6 were considered as having "very poor" completion.
Among 21 birth-related variables, 9 (42.8\%) had "excellent" and 5 had "very poor" (23.8\%) filling levels. For the fetal component, the variable with the lowest completeness was "amniotic fluid odor" (7.5\%), and for the preterm neonatal it was "caesarean section indication" (13.7\%) (Table 3).

In the "family characteristics" block, among 12 variables, 8 were classified as having "regular" completion, and 4 as having "poor" completion. As for the fields related to "occurrence of death," among 11 variables, 3 had "excellent" completion, and 3 had "very poor" completion ("perinatal" general category). Variables with the best filling levels were "place of occurrence" $(99.4 \%)$ and "necropsy" (99.4\%), in the fetal component. In the preterm neonatal component, "place of occurrence" and "unit type" stood out with $100 \%$ completion (Table 4).

In the block of variables related to conclusions and recommendations, $5(8.9 \%)$ were considered to have "excellent" completion. Variables with the best percentage of completeness in the perinatal general category were "avoidability classification," and whether the investigation changed or corrected the cause of death, with $100 \%$ completion for both (Table 5).

Table 1 - Descriptive statistics: completeness of perinatal death investigation sheets, according to variable block, Recife, Pernambuco, Brazil, 2014

\begin{tabular}{|c|c|c|c|c|c|c|c|c|c|c|c|c|}
\hline \multirow{3}{*}{ Variable block } & \multirow{2}{*}{\multicolumn{4}{|c|}{ Perinatal }} & \multicolumn{8}{|c|}{ Age components } \\
\hline & & & & & \multicolumn{4}{|c|}{ Fetal } & \multicolumn{4}{|c|}{ Preterm neonatal } \\
\hline & Mean \pm SD & Median & Min. & Max. & Mean \pm SD & Median & Min. & Max. & Mean \pm SD & Median & Min. & Max. \\
\hline Identification & $82.5 \pm 18.05$ & 96.1 & 40 & 100 & $84.4 \pm 18.96$ & 94.7 & 44.4 & 100 & $92.2 \pm 19.83$ & 97.9 & 32.6 & 100 \\
\hline Prenatal care & $67.6 \pm 25,9$ & 69.8 & 26.7 & 98.4 & $67.6 \pm 25.7$ & 73.8 & 26.3 & 98.1 & $67.6 \pm 26.5$ & 67.4 & 24.2 & 100 \\
\hline Birth care & $74.1 \pm 31.6$ & 87.1 & 10.6 & 100 & $66.2 \pm 37$ & 81.9 & 7.5 & 100 & $76 \pm 30$ & 89.5 & 13.7 & 100 \\
\hline Family characteristics & $79.2 \pm 6$ & 82.4 & 62.4 & 83.5 & $77.4 \pm 5$ & 79.4 & 63.1 & 81.3 & $82.4 \pm 7.8$ & 86.3 & 61.1 & 87.4 \\
\hline Occurrence of death & $69.7 \pm 32.9$ & 80 & 15.3 & 99.6 & $73.2 \pm 29.2$ & 82.8 & 30 & 7.4 & $70.5 \pm 35.8$ & 82.1 & 7.4 & 100 \\
\hline Conclusions and recommendations & $78.6 \pm 22.9$ & 85.7 & 12.2 & 100 & $80.9 \pm 19.8$ & 85 & 10.6 & 100 & $86.1 \pm 17.1$ & 91.6 & 14.7 & 100 \\
\hline
\end{tabular}

Note: SD: Standard Deviation.

Table 2 - Completeness of variables in the "identification" block of perinatal death investigation sheets, Recife, Pernambuco, Brazil, 2014

\begin{tabular}{|c|c|c|c|c|c|c|c|c|c|}
\hline \multirow{3}{*}{ Variables } & \multirow{2}{*}{\multicolumn{3}{|c|}{ Perinatal }} & \multicolumn{6}{|c|}{ Age components } \\
\hline & & & & \multicolumn{3}{|c|}{ Fetal } & \multicolumn{3}{|c|}{ Preterm neonatal } \\
\hline & $\mathbf{n}$ & $\%$ & $\mathrm{Cl}^{*}$ & $\mathbf{n}$ & $\%$ & $\mathrm{Cl} *$ & $\mathbf{n}$ & $\%$ & $\mathrm{Cl}^{*}$ \\
\hline Moment of death & 255 & 100.0 & $E$ & 160 & 100.0 & $E$ & 95 & 100.0 & $E$ \\
\hline Sex & 255 & 100.0 & $E$ & 160 & 100.0 & $\mathrm{E}$ & 95 & 100.0 & $\mathrm{E}$ \\
\hline Age & 94 & 98.9 & $E$ & NA & & & 94 & 98.9 & $E$ \\
\hline Race/color & 200 & 78.4 & $P$ & 110 & 68.8 & $P$ & 90 & 94.7 & G \\
\hline Mother's age & 253 & 99.2 & $E$ & 158 & 98.8 & $E$ & 95 & 100.0 & $\mathrm{E}$ \\
\hline Mother's race/color & 200 & 78.4 & $P$ & 110 & 68.8 & $P$ & 90 & 94.7 & G \\
\hline Mother's level of education & 244 & 95.7 & $E$ & 151 & 94.4 & B & 93 & 97.9 & $\mathrm{E}$ \\
\hline Mother's occupation & 245 & 96.1 & $E$ & 152 & 95.0 & B & 93 & 97.9 & $\mathrm{E}$ \\
\hline Marital status & 215 & 84.3 & $\mathrm{RE}$ & 122 & 76.3 & $P$ & 93 & 97.9 & $E$ \\
\hline Partner occupation & 102 & 40.0 & VP & 71 & 44.4 & VP & 31 & 32.6 & VP \\
\hline Area covered by the FHS & 250 & 98.0 & $E$ & 156 & 97.5 & $E$ & 94 & 98.9 & $E$ \\
\hline Block average & 82.5 & & & 84.4 & & & 92.2 & & \\
\hline
\end{tabular}

Note: ${ }^{*}$ classification; $F H S=$ Family Health Strategy; $E=$ excellent; $G=$ good; $R E=$ regular; $P=$ poor; $V P=$ very poor, $N A=$ not applicable 
Table 3 - Completeness of variables in the "prenatal care" and "birth care" blocks of perinatal death investigation sheets, Recife, Pernambuco, Brazil, 2014

\begin{tabular}{|c|c|c|c|c|c|c|c|c|c|}
\hline \multirow{3}{*}{ Variables } & \multirow{2}{*}{\multicolumn{3}{|c|}{ Perinatal }} & \multicolumn{6}{|c|}{ Age components } \\
\hline & & & & \multicolumn{3}{|c|}{ Fetal } & \multicolumn{3}{|c|}{ Preterm neonatal } \\
\hline & $\mathbf{n}$ & $\%$ & $\mathrm{Cl}^{*}$ & $\mathbf{n}$ & $\%$ & $\mathrm{Cl}^{*}$ & $\mathbf{n}$ & $\%$ & $\mathrm{Cl} *$ \\
\hline \multicolumn{10}{|l|}{ Prenatal care } \\
\hline Prenatal & 251 & 98.4 & E & 156 & 97.5 & E & 95 & 100.0 & $E$ \\
\hline Prenatal unit type & 204 & 80.0 & $\mathrm{R}$ & 135 & 84.4 & RE & 69 & 72.6 & $\mathrm{R}$ \\
\hline Starting month of prenatal period & 199 & 78.0 & $\mathrm{R}$ & 123 & 76.9 & $\mathrm{R}$ & 76 & 80.0 & $\mathrm{R}$ \\
\hline Number of medical consultations & 205 & 80.4 & RE & 129 & 80.6 & RE & 76 & 80.0 & $\mathrm{R}$ \\
\hline Familial antecedents & 149 & 58.4 & $\mathrm{R}$ & 94 & 58.8 & $\mathrm{R}$ & 55 & 57.9 & $\mathrm{R}$ \\
\hline Personal antecedents & 116 & 45.5 & MR & 69 & 43.1 & MR & 47 & 49.5 & MR \\
\hline Complementary examinations & 161 & 63.1 & $\mathrm{R}$ & 104 & 65.0 & $\mathrm{R}$ & 57 & 60.0 & $\mathrm{R}$ \\
\hline Procedures & 178 & 69.8 & $\mathrm{R}$ & 118 & 73.8 & $\mathrm{R}$ & 60 & 63.2 & $\mathrm{R}$ \\
\hline Risk factors & 120 & 47.1 & MR & 74 & 46.3 & MR & 46 & 48.4 & $M R$ \\
\hline Complications & 170 & 66.7 & $\mathrm{R}$ & 106 & 66.3 & $\mathrm{R}$ & 64 & 67.4 & $\mathrm{R}$ \\
\hline Treatment & 84 & 32.9 & MR & 52 & 32.5 & MR & 32 & 33.7 & MR \\
\hline Number of previous pregnancies & 251 & 98.4 & $E$ & 157 & 98.1 & E & 94 & 98.9 & E \\
\hline Number of vaginal deliveries & 233 & 91.4 & B & 142 & 88.8 & RE & 91 & 95.8 & $E$ \\
\hline Number of cesarean deliveries & 232 & 91.0 & $\mathrm{~B}$ & 141 & 88.1 & RE & 91 & 95.8 & $\mathrm{E}$ \\
\hline Number of live births & 250 & 98.0 & $\mathrm{E}$ & 156 & 97.5 & $\mathrm{E}$ & 94 & 98.9 & $\mathrm{E}$ \\
\hline Number of fetal losses/abortions & 251 & 98.4 & $\mathrm{E}$ & 157 & 98.1 & $\mathrm{E}$ & 94 & 98.9 & $\mathrm{E}$ \\
\hline Interval between the last two pregnancies & 79 & 31.0 & MR & 56 & 35.0 & MR & 23 & 24.2 & MR \\
\hline Pre-gestational weight & 74 & 29.0 & MR & 43 & 26.9 & MR & 31 & 32.6 & $M R$ \\
\hline Maternal height & 68 & 26.7 & MR & 42 & 26.3 & MR & 26 & 27.4 & MR \\
\hline \multicolumn{10}{|l|}{ Birth care } \\
\hline Place of birth & 255 & 100.0 & $\mathrm{E}$ & 160 & 100.0 & $\mathrm{E}$ & 95 & 100.0 & $\mathrm{E}$ \\
\hline Birth unit type & 252 & 98.8 & $E$ & 158 & 98.8 & $\mathrm{E}$ & 94 & 98.9 & $E$ \\
\hline Partogram & 49 & 51.6 & $\mathrm{R}$ & & NA & & 49 & 51.6 & $\mathrm{R}$ \\
\hline Induction of childbirth & 211 & 82.7 & RE & 134 & 83.8 & RE & 77 & 81.1 & RE \\
\hline Rapid syphilis test & 222 & 87.1 & RE & 137 & 85.6 & RE & 85 & 89.5 & RE \\
\hline HIV rapid test & 198 & 77.6 & $\mathrm{R}$ & 126 & 78.8 & $\mathrm{R}$ & 72 & 75.8 & $\mathrm{R}$ \\
\hline Gestational age & 253 & 99.2 & $E$ & 158 & 98.8 & $E$ & 95 & 100.0 & $\mathrm{E}$ \\
\hline Type of pregnancy & 255 & 100.0 & $E$ & 160 & 100.0 & $E$ & 95 & 100.0 & $E$ \\
\hline Type of birth & 255 & 100.0 & $E$ & 160 & 100.0 & $E$ & 95 & 100.0 & $E$ \\
\hline Caesarean section indication & 53 & 20.8 & MR & 40 & 25.0 & MR & 13 & 13.7 & $M R$ \\
\hline Pre-delivery intervention & 36 & 14.1 & MR & 15 & 9.4 & MR & 21 & 22.1 & MR \\
\hline Sac rupture time & 76 & 29.8 & MR & 34 & 21.3 & MR & 42 & 44.2 & MR \\
\hline Amniotic fluid odor & 27 & 10.6 & MR & 12 & 7.5 & MR & 15 & 15.8 & MR \\
\hline Appearance of amniotic fluid & 111 & 43.5 & MR & 60 & 37.5 & MR & 51 & 53.7 & $\mathrm{R}$ \\
\hline Birth weight & 255 & 100.0 & $\mathrm{E}$ & 160 & 100.0 & $E$ & 95 & 100.0 & $E$ \\
\hline Assisted birth & 219 & 85.9 & RE & 128 & 80.0 & $\mathrm{R}$ & 91 & 95.8 & $\mathrm{E}$ \\
\hline Apgar score 1-min & 91 & 95.8 & $\mathrm{E}$ & & NA & & 91 & 95.8 & $\mathrm{E}$ \\
\hline Apgar score 5-min & 92 & 96.8 & $\mathrm{E}$ & & NA & & 92 & 96.8 & $E$ \\
\hline NB with issues & 84 & 88.4 & RE & & NA & & 84 & 88.4 & RE \\
\hline NB length of stay in maternity ward & 94 & 98.9 & $E$ & & NA & & 94 & 98.9 & $E$ \\
\hline Reason for permanence & 70 & 73.7 & $\mathrm{R}$ & & NA & & 70 & 73.7 & $\mathrm{R}$ \\
\hline
\end{tabular}

Note: ${ }^{*}$ classification; $N B=$ Newborn; $E=$ excellent; $G=$ good; $R E=$ regular; $P=$ poor; $V P=$ very poor, $N A=$ not applicable

Table 4 - Completeness of variables related to "family characteristics" and "occurrence of death" in perinatal death investigation sheets, Recife, Pernambuco, Brazil, 2014

\begin{tabular}{|c|c|c|c|c|c|c|c|c|c|}
\hline \multirow{3}{*}{ Variables } & \multirow{2}{*}{\multicolumn{3}{|c|}{ Perinatal }} & \multicolumn{6}{|c|}{ Age components } \\
\hline & & & & \multicolumn{3}{|c|}{ Fetal } & \multicolumn{3}{|c|}{ Preterm neonatal } \\
\hline & $\mathbf{n}$ & $\%$ & $\mathrm{Cl} *$ & $\mathbf{n}$ & $\%$ & $\mathrm{Cl}^{*}$ & $\mathbf{n}$ & $\%$ & $\mathrm{Cl}^{*}$ \\
\hline \multicolumn{10}{|l|}{ Family characteristics } \\
\hline Private health plan & 194 & 76.1 & $\mathrm{P}$ & 120 & 75.0 & $\mathrm{P}$ & 74 & 77.9 & $\mathrm{P}$ \\
\hline Family income & 196 & 76.9 & $\mathrm{P}$ & 122 & 76.3 & $\mathrm{P}$ & 74 & 77.9 & $\mathrm{P}$ \\
\hline Number of inhabitants in the residence & 210 & 82.4 & RE & 127 & 79.4 & $P$ & 83 & 87.4 & RE \\
\hline
\end{tabular}




\begin{tabular}{|c|c|c|c|c|c|c|c|c|c|}
\hline \multirow{3}{*}{ Variables } & \multirow{2}{*}{\multicolumn{3}{|c|}{ Perinatal }} & \multicolumn{6}{|c|}{ Age components } \\
\hline & & & & \multicolumn{3}{|c|}{ Fetal } & \multicolumn{3}{|c|}{ Preterm neonatal } \\
\hline & $\mathbf{n}$ & $\%$ & $\mathrm{Cl} *$ & $\mathbf{n}$ & $\%$ & $\mathrm{Cl} *$ & $\mathbf{n}$ & $\%$ & $\mathrm{Cl}^{*}$ \\
\hline Number of $\leq 5$ years old children & 159 & 62.4 & $P$ & 101 & 63.1 & $P$ & 58 & 61.1 & $\mathrm{P}$ \\
\hline Number of dormitory rooms & 210 & 82.4 & RE & 127 & 79.4 & $\mathrm{P}$ & 83 & 87.4 & RE \\
\hline Dwelling type & 210 & 82.4 & RE & 128 & 80.0 & $\mathrm{P}$ & 82 & 86.3 & RE \\
\hline House construction material & 211 & 82.7 & RE & 129 & 80.6 & RE & 82 & 86.3 & RE \\
\hline Water supply & 213 & 83.5 & RE & 130 & 81.3 & RE & 83 & 87.4 & RE \\
\hline Destination of bodily waste & 212 & 83.1 & RE & 129 & 80.6 & RE & 83 & 87.4 & RE \\
\hline Destination of trash & 210 & 82.4 & RE & 127 & 79.4 & $\mathrm{P}$ & 83 & 87.4 & RE \\
\hline Access to health services & 205 & 80.4 & RE & 126 & 78.8 & $\mathrm{P}$ & 79 & 83.2 & RE \\
\hline Availability of medical consultations & 195 & 76.5 & $\mathrm{P}$ & 120 & 75.0 & $\mathrm{P}$ & 75 & 78.9 & $\mathrm{P}$ \\
\hline \multicolumn{10}{|l|}{ Occurrence of death } \\
\hline Place of occurrence & 254 & 99.61 & $\mathrm{E}$ & 159 & 99.4 & $\mathrm{E}$ & 95 & 100.0 & $\mathrm{E}$ \\
\hline Unit type & 253 & 99.22 & $\mathrm{E}$ & 158 & 98.8 & $\mathrm{E}$ & 95 & 100.0 & $\mathrm{E}$ \\
\hline Hospital length of stay & 89 & 93.68 & G & NA & & & 89 & 93.7 & G \\
\hline Sector of occurrence & 76 & 80.00 & $\mathrm{P}$ & NA & & & 76 & 80.0 & $\mathrm{P}$ \\
\hline Child/mother transferred from another unit & 204 & 80.00 & $\mathrm{P}$ & 113 & 70.6 & $P$ & 91 & 95.8 & $\mathrm{E}$ \\
\hline General condition at admission & 39 & 15.29 & VP & NA & & & 35 & 36.8 & VP \\
\hline Diagnostic hypothesis at admission & 165 & 64.71 & $\mathrm{P}$ & 87 & 54.4 & $P$ & 78 & 82.1 & RE \\
\hline Final diagnosis & 228 & 89.41 & RE & 152 & 95.0 & G & 76 & 80.0 & $\mathrm{P}$ \\
\hline Necropsy & 247 & 96.86 & $\mathrm{E}$ & 159 & 99.4 & $\mathrm{E}$ & 88 & 92.6 & G \\
\hline Necropsy site & 68 & 26.67 & VP & 61 & 38.1 & VP & 7 & 7.4 & $\mathrm{P}$ \\
\hline Necroscopic report & 55 & 21.57 & VP & 48 & 30.0 & VP & 7 & 7.4 & $\mathrm{P}$ \\
\hline
\end{tabular}

Note: ${ }^{*}$ classification; $E=$ excellent; $G=\operatorname{good} ; R E=$ regular; $P=$ poor; $V P=$ very poor, $N A=$ not applicable

Table 5 - Completeness of variables in the conclusions and recommendations block of perinatal death investigation sheets, Recife, Pernambuco, Brazil, 2014

\begin{tabular}{|c|c|c|c|c|c|c|c|c|c|}
\hline \multirow{3}{*}{ Variables } & \multirow{2}{*}{\multicolumn{3}{|c|}{ Perinatal }} & \multicolumn{6}{|c|}{ Age components } \\
\hline & & & & \multicolumn{3}{|c|}{ Fetal } & \multicolumn{3}{|c|}{ Preterm neonatal } \\
\hline & $\mathbf{n}$ & $\%$ & $\mathrm{Cl} *$ & $\mathbf{n}$ & $\%$ & $\mathrm{Cl}^{*}$ & $\mathbf{n}$ & $\%$ & $\mathrm{Cl}^{*}$ \\
\hline Investigation changed/corrected cause of death & 255 & 100.0 & E & 160 & 100.0 & E & 95 & 100.0 & $\mathrm{E}$ \\
\hline Investigation changed another field of the death declaration & 254 & 99.6 & $\mathrm{E}$ & 160 & 100.0 & $\mathrm{E}$ & 94 & 98.9 & $\mathrm{E}$ \\
\hline Investigation changed another field of the live birth declaration & 87 & 96.1 & E & & NA & & 87 & 91.6 & G \\
\hline Issues identified after investigation & 249 & 97.6 & E & 155 & 96.9 & $\mathrm{E}$ & 94 & 98.9 & $\mathrm{E}$ \\
\hline \multicolumn{10}{|l|}{ Access failure } \\
\hline To family planning & 231 & 90.6 & G & 142 & 88.8 & RE & 89 & 93.7 & G \\
\hline To prenatal care & 235 & 92.2 & G & 144 & 90.0 & G & 91 & 95.8 & $\mathrm{E}$ \\
\hline To childbirth assistance & 223 & 87.5 & RE & 136 & 85.0 & RE & 87 & 91.6 & G \\
\hline To maternity ward newborn assistance & 69 & 72.6 & $\mathrm{P}$ & & NA & & 69 & 72.6 & $\mathrm{P}$ \\
\hline Due to family difficulties & 212 & 83.1 & RE & 127 & 79.4 & $P$ & 85 & 89.5 & RE \\
\hline \multicolumn{10}{|l|}{ Care failure } \\
\hline Family planning & 229 & 89.8 & $\mathrm{RE}$ & 141 & 88.1 & RE & 88 & 92.6 & G \\
\hline Prenatal care & 234 & 91.8 & G & 145 & 90.6 & G & 89 & 93.7 & G \\
\hline Delivery & 224 & 87.8 & RE & 135 & 84.4 & RE & 89 & 93.7 & G \\
\hline Maternity ward newborn assistance & 68 & 71.6 & $\mathrm{P}$ & & NA & & 68 & 71.6 & $\mathrm{P}$ \\
\hline Due to family difficulties & 214 & 83.9 & RE & 127 & 79.4 & $P$ & 87 & 91.6 & G \\
\hline External causes & 31 & 12.2 & VP & 17 & 10.6 & VP & 14 & 14.7 & VP \\
\hline In primary care coverage & 227 & 89.0 & RE & 138 & 86.3 & RE & 89 & 93.7 & G \\
\hline In reference and counter-reference & 198 & 77.6 & $\mathrm{P}$ & 117 & 73.1 & $\mathrm{P}$ & 81 & 85.3 & RE \\
\hline In high-risk prenatal care & 196 & 76.9 & $\mathrm{P}$ & 116 & 72.5 & $\mathrm{P}$ & 80 & 84.2 & RE \\
\hline In a bed in the high-risk pregnancy intensive care unit & 192 & 75.3 & $\mathrm{P}$ & 113 & 70.6 & $P$ & 79 & 83.2 & RE \\
\hline In a bed in the neonatal intensive care unit & 80 & 31.4 & VP & & NA & & 80 & 84.2 & RE \\
\hline In the control center & 192 & 75.3 & $\mathrm{P}$ & 113 & 70.6 & $P$ & 79 & 83.2 & RE \\
\hline In inter-hospital transport & 191 & 74.9 & $\mathrm{P}$ & 113 & 70.6 & $P$ & 78 & 82.1 & RE \\
\hline In blood banks & 77 & 30.2 & VP & & NA & & 77 & 81.1 & RE \\
\hline Avoidability classification & 255 & 100.0 & $\mathrm{E}$ & 160 & 100.0 & $\mathrm{E}$ & 95 & 100.0 & $\mathrm{E}$ \\
\hline
\end{tabular}

Note: ${ }^{*}$ classification; $E=$ excellent; $G=$ good; $R E=$ regular; $P=$ poor; $V P=$ very poor, $N A=$ not applicable. 


\section{DISCUSSION}

The completeness of the research records was classified as "good," and the comparison between components showed that almost all of the analyzed data blocks had better completeness in the preterm neonatal component. Data on stillbirths are usually deficient and of inferior quality, mainly in respect to sociodemographic and care-related information ${ }^{(5,14)}$. The low quality of data on stillbirths limits its use for the proposition of actions directed at its confrontation ${ }^{(2)}$.

The importance (or lack thereof) given to filling information on fetal mortality is one of the main factors associated with incompleteness of data ${ }^{(15)}$. In Brazil, despite the declining trend of the stillbirth rate, it is still almost twice as high the one found in developed countries ${ }^{(16)}$. In addition, mortality differentials between states are significant ${ }^{(17)}$.

Most "identification" block data were rated as "excellent" in both components, similar to what was found by recent assessments of vital statistics information systems, which demonstrated improved data quality ${ }^{(9,11)}$. After the implementation of infant and fetal death surveillance in Recife, confirmation of provided information became a requirement, and the proportion of blank and ignored fields was significantly reduced ${ }^{(10)}$.

Regarding variables in the "prenatal care" block, "risk factors," "personal antecedents," "interval between the last two pregnancies," "pre-gestational weight" and "maternal height" presented "very poor" completeness. Admittedly, data on preexisting maternal conditions are poorly reported ${ }^{(18)}$. While an interview with the mother is considered the gold standard for obtaining information on maternal behaviors ${ }^{(19)}$, the inadequate completion of this information makes it difficult to understand the circumstances of death, the evaluation of the assistance offered to the pregnant woman and to the fetus or newborn, and the evaluation of socioeconomic conditions. This data could assist in interventions to reduce the occurrence of avoidable deaths ${ }^{(10,13)}$.

A study carried out in Alagoas ${ }^{(11)}$ showed that the filling level of variables related to prenatal care was poor, and a study carried out in Pernambuco ${ }^{(20)}$ also pointed out a greater inadequacy of the prenatal care block in investigation sheets of a group of children who did not receive medical discharge after birth. Inadequate completion of information on prenatal care makes it difficult to assess maternal and child care, and perpetuates deficiencies mainly in primary care and in the prevention of avoidable deaths. In this sense, a study showed that mothers with inadequate prenatal care have a higher chance of death ${ }^{(21)}$, and a recent evaluation of quality of prenatal care provided in the basic health network throughout Brazil revealed that only $15 \%$ of respondents received quality care according to the following parameters: number of visits, vaccination status, prescription of ferrous sulfate, physical examination, medical advice and complementary examinations ${ }^{(22)}$.

Birth information obtained a classification of "good." A systematic review study found that procedures and conditions that occur close to birth have more reliable records, probably due to better access to clinical records that make it possible to complete the information ${ }^{(23)}$. At the national level, the Information
System on Live Births (Sinasc) was evaluated as good quality and as having high completeness ${ }^{(24)}$. A hospital investigation of perinatal deaths in Ethiopia showed their avoidability, and that factors related to the health worker were the most commonly identified, followed by those referring to the patient and administrative factors ${ }^{(19)}$. Measures to improve the quality of care are linked to the improvement of information quality and completeness, in order to allow the recognition of each health service's current situation, allowing for the planning of adequate interventions.

Variables related to family characteristics were classified as "good." The evaluation of the socioeconomic context in which death occurred contributes to the planning and implementation of intersectoral actions ${ }^{(10,25)}$.

The completeness of data related to conclusions and recommendations was good, an indication that the completion of the investigation steps was satisfactory and provided an assessment of problems, as well as the suggestion of measures to prevent avoidable perinatal deaths $s^{(8,10)}$. The change or correction of the cause of death can be considered indicative of the adequacy of infant death surveillance actions ${ }^{(26)}$.

\section{Limitations of this study}

The study is limited by its use of a non-specific completeness score to evaluate perinatal death investigation sheets. However, the small number of studies analyzing the investigation sheet and its contribution to death surveillance attests this study's relevance.

Contributions to the area of nursing, health or public policy Complete epidemiological investigation optimizes the targeting of public resources and actions to reduce perinatal mortality. Analysis of completeness allows the evaluation of the information and contributes to its qualification. For the death investigation to be fully successful, it is essential for it to have reliable information, so that it can properly intervene on the identified gaps and propose effective measures for the prevention and reduction of perinatal mortality.

\section{CONCLUSION}

This assessment of the completeness of perinatal death investigation sheets ranked overall completion level as "good." However, there are considerable differences in completeness between variables and components. In order for death surveillance to play its role of providing information on deficiencies in the maternal and child healthcare process and help direct interventions to the issue of avoidable deaths, it is crucial to ensure the proper filling out of the investigation sheet.

\section{FUNDING}

Research funded by the National Council of Scientific and Technological Development/CNPq (Process number 480718/2012-1) and by the Foundation of Science and Technology Support of Pernambuco/Facepe (Process number 2133-4.0012). 


\section{REFERENCES}

1. Merali HS, Lipsitz S, Hevelone N, Gawande AA, Lashoher A, Agrawal P, et al. Audit-identified avoidable factors in maternal and perinatal deaths in low resource settings: a systematic review. BMC Pregnancy Childbirth[Internet]. 2014 [cited 2017 Oct 20];14(280):1-12. Available from: https://bmcpregnancychildbirth.biomedcentral.com/articles/10.1186/1471-2393-14-280

2. Masson VL, Farquhar CM, Sadler LC. Validation of local review for the identification of contributory factors and potentially avoidable perinatal deaths. Aust N Z J Obstet Gynaecol[Internet]. 2016[cited 2017 Oct 18];56(3):282-8. Available from: https://www.ncbi. nlm.nih.gov/pubmed/26948578

3. Brasil. Ministério da Saúde. DATASUS. Informações de Saúde. Estatísticas vitais. Mortalidade e nascidos vivos: óbitos perinatais[Internet]. 2015[cited 2017 Oct 10]. Available from: http://tabnet.datasus.gov.br/cgi/deftohtm.exe?sim/cnv/fet10pe.def

4. Lawn JE, Blencowe H, Oza S, You D, Lee AC, Waiswa P, et al. Every newborn: progress, priorities, and potential beyond survival. Lancet[Internet]. 2014[cited 2017 Aug 18];384(9938):189-205. Available from: http://www.thelancet.com/pdfs/journals/lancet/ PIIS0140-6736(14)60496-7.pdf

5. Blencowe H, Calvert PhD C, Lawn JE, Cousens S, Campbell OM. Measuring maternal, fetal and neonatal mortality: challenges and solutions. Best Pract Res Clin Obstet Gynaecol[Internet]. 2016[cited 2017 Aug 20];36:14-29. Available from: http://researchonline. Ishtm.ac.uk/2665971/1/unedited_proofs.pdf

6. Lee EJ, Gambatese M, Begier E, Soto A, Das T, Madsen A. Understanding perinatal death: a systematic analysis of New York City fetal and neonatal death vital record data and implications for improvement, 2007-2011. Matern Child Health J[Internet]. 2014[cited 2017 Aug 20];18(8):1945-54. Available from: https://www.ncbi.nlm.nih.gov/pubmed/24522520

7. Grove J, Claeson M, Bryce J, Amouzou A, Boerma T, Waiswa P, et al. Maternal, newborn, and child health and the Sustainable Development Goals - a call for sustained and improved measurement. Lancet[Internet]. 2015[cited 2017 Aug 20];386(10003):15114. Available from: http://www.thelancet.com/pdfs/journals/lancet/PIIS0140-6736(15)00517-6.pdf

8. Venâncio S, Paiva R. The installation of Child Mortality Investigation Committees in the state of São Paulo. Rev Bras Saúde Mater Infant[Internet]. 2010[cited 2017 Aug 20];10(3):369-75. Available from: http://www.scielo.br/pdf/rbsmi/v10n3/v10n3a10.pdf

9. Oliveira CM, Bonfim CV, Guimarães MJB, Frias PG, Antonino VCS, Medeiros ZM. Infant mortality surveillance in Recife, Pernambuco, Brazil: operationalization, strengths and limitations. Epidemiol Serv Saúde[Internet]. 2017[cited 2017 Aug 20];26(2):413-9. Available from: http://www.scielo.br/pdf/ress/v26n2/en_2237-9622-ress-26-02-00413.pdf

10. Oliveira CM, Bonfim CV, Guimarães MJB, Frias PG, Medeiros ZM. Infant mortality: temporal trend and contribution of death surveillance. Acta Paul Enferm[Internet]. 2016[cited 2017 Aug 20];29(3):282-90. Available from: http://www.scielo.br/pdf/ape/ v29n3/1982-0194-ape-29-03-0282.pdf

11. Caetano SF, Vanderlei LC, Frias PG. Evaluation of completeness of instruments for research on child death in the City of Arapiraca, Alagoas. Cad Saúde Colet[Internet]. 2013[cited 2017 Aug 20];21(3):309-17. Available from: http://www.scielo.br/pdf/cadsc/v21n3/ v21n3a12.pdf

12. Brasil. Instituto Brasileiro de Geografia e Estatística-IBGE. Cidades: Recife[Internet]. 2014[cited 2018 Apr 10]. Available from: https://cidades.ibge.gov.br/xtras/perfil.php?codmun $=261160$

13. Romero DE, Cunha CB. Evaluation of quality of epidemiological and demographic variables in the Live Births Information System, 2002. Cad Saúde Pública[Internet]. 2007[cited 2017 Aug 20];23(3):701-14. Available from: http://www.scielo.br/pdf/csp/v23n3/28.pdf

14. Ramalho MO, Frias PG, Vanderlei LC, Macedo VC, Lira PI. Evaluation of the incompleteness in the filling out of death certificates of children under one year of age in the state of Pernambuco, Brazil, 1999-2011. Ciênc Saúde Colet[Internet]. 2015[cited 2017 Aug 20];20(9):2891-8. Available from: http://www.scielo.br/pdf/csc/v20n9/1413-8123-csc-20-09-2891.pdf

15. Wingate MS, Barfield WD, Smith RA, Petrini J. Perinatal disparities between American Indians and Alaska natives and other US populations: comparative changes in fetal and first day mortality, 1995-2008. Matern Child Health J[Internet]. 2015[cited 2017 Aug 20];19(8):1802-12. Available from: https://link.springer.com/article/10.1007\%2Fs10995-015-1694-1

16. Vieira MSM, Vieira FM, Fröde TS, D'Orsi E. Fetal deaths in Brazil: historical series descriptive analysis 1996-2012. Matern Child Health J[Internet]. 2016[cited 2018 Apr 10];20(8):1634-50. Available from: https://link.springer.com/article/10.1007\%2Fs10995- 016-1962-8

17. Frias PGD, Szwarcwald CL, Souza Jr PRBD, Almeida WDSD, Lira PIC. Correção de informações vitais: estimação da mortalidade infantil, Brasil, 2000-2009. Rev Saúde Pública[Internet]. 2013[cited 2018 Apr 10];47(6):1048-58. Available from: https://www. scielosp.org/article/rsp/2013.v47n6/1048-1058/pt/

18. Roos N, von Xylander SR. Why do maternal and newborn deaths continue to occur? Best Pract Res Clin Obstet Gynaecol[Internet] 2016[cited 2017 Aug 20];36:30-44. Available from: https://www.ncbi.nlm.nih.gov/pubmed/27506412

19. Demise A, Gebrehiwot Y, Worku B, Spector JM. Prospective audit of avoidable factors in institutional stillbirths and early neonatal deaths at Tikur Anbessa Hospital in Addis Ababa, Ethiopia. Afr J Reprod Health[Internet]. 2015[cited 2017 Aug 20];19(4):78-86. Available from: https://www.ncbi.nlm.nih.gov/pubmed/27337856

20. Oliveira CM, Guimarães MJB, Bonfim CV, Frias PG, Antonino VCS, Guimarães ALS. Evaluation of the adequacy of information 
from research on infant mortality in Recife, Pernambuco, Brazil. Ciênc Saúde Colet[Internet]. 2018[cited 2018 Apr 12];23(3):70114. Available from: http://www.scielo.br/pdf/csc/v23n3/en_1413-8123-csc-23-03-0701.pdf

21. Santos SLD, Santos LB, Campelo V, Silva ARV. Factors associated with infant mortality in a northeastern Brazilian capital. Rev Bras Ginecol Obstet[Internet]. 2016[cited 2017 Aug 20];38(10):482-91. Available from: http://www.scielo.br/pdf/rbgo/v38n10/01007203-rbgo-38-10-00482.pdf

22. Tomasi E, Fernandes PAA, Fischer T, Siqueira FCV, Silveira DS, Thumé E. Quality of prenatal services in primary healthcare in Brazil: indicators and social inequalities. Cad Saúde Pública[Internet]. 2017[cited 2018 Apr 12];33(3):e00195815. Available from: http://www.scielo.br/pdf/csp/v33n3/1678-4464-csp-33-03-e00195815.pdf

23. Correia LOS, Padilha BM, Vasconcelos SML. Methods for assessing the completeness of data in health information systems in Brazil: a systematic review. Ciênc Saúde Colet[Internet]. 2014[cited 2017 Aug 20];19(11):4467-78. Available from: http://www. scielo.br/pdf/csc/v19n11/1413-8123-csc-19-11-4467.pdf

24. Oliveira MM, Andrade SSCA, Dimech GS, Oliveira JCG, Malta DC, Rabelo Neto DL, et al. Evaluation of the National Information System on Live Births in Brazil, 2006-2010. Epidemiol Serv Saúde[Internet]. 2015[cited 2017 Aug 20];24(4):629-40. Available from: http://www.scielo.br/pdf/ress/v24n4/2237-9622-ress-24-04-00629.pdf

25. Delnord K. Linking databases on perinatal health: a review of the literature and current practices in Europe M. and the Euro-Peristat Scientific Committee. Eur J Public Health[Internet]. 2016[cited 2017 Sept 20];26(3):422-30. Available from: https://www.ncbi.nlm. nih.gov/pmc/articles/PMC4884328/pdf/ckv231.pdf

26. Marques LJP, Pimentel DDR, Oliveira CMD, Vilela MBR, Frias PG, Bonfim CVD. Agreement between underlying cause and preventability of infant deaths before and after the investigation in Recife, Pernambuco State, Brazil, 2014. Epidemiol Serv Saúde[Internet]. 2018[cited 2018 Apr 12];27(1):e20170557. Available from: http://www.scielo.br/pdf/ress/v27n1/en_2237-9622ress-27-01-e20170557.pdf 